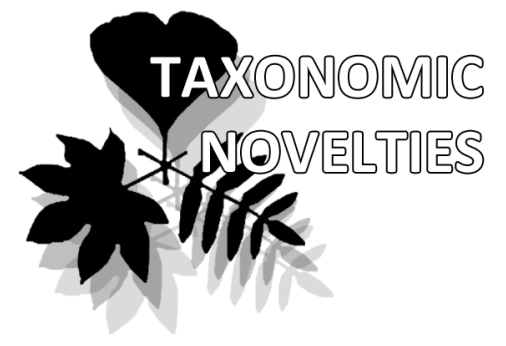

Michael G. Pimenov

e-mail: mgpimenov@mail.ru

Botanical Garden, Lomonosov Moscow State University, Moscow, Russia

Manuscript received: 26.07 .2017 Review completed: 03.11.2017 Accepted for publication: 21.11.2017 Published online: 25.11.2017

\section{Novelties in Myanmar Umbelliferae: a new species of Oenanthe L. and two new floristic records}

\author{
Michael G. Pimenov
}

\begin{abstract}
A B S T R A C T
Oenanthe hortorum-natantium is described and illustrated as a new species, endemic to Myanmar (former Burma). It differs from closely related species of sect. Dasyloma in dissection of leaf laminas, and the form of terminal leaf segments, as well as some characters of lifeform. Two other Umbels species, widely distributed in tropical and subtropical regions, Hydrocotyle verticillata and Cyclospermum leptophylum had been recorded for Myanmar flora for the first time.
\end{abstract}

K e y w o r d s : Apiaceae, Oenanthe, Hydrocotyle, Cyclospermum, Myanmar, Burma, new species, new records

\section{P E 3 Ю ME}

Пименов М.Г. Новинки Umbelliferae Мьянмы - новый виА Oenanthe и Аве новые фмористические находки. Описан и илмюстритован новый виА Oenanthe hortorum-natantium, эндемичный Аля Мьянмы (бывшая Бирма). Он отличается от близких видов секции Dasyloma рассечением пластинок мистьев и формой конечных мистовых сегментов, а также особенностями жизненной формы. Ава Аругих вила зонтичных, Hydrocotyle verticillata и Cyclospermum leptophyllum, впервые указанные Аля Мьянмы, широко распространены в тропиках и суб̆тропиках.

Ки юч е в ы е с $\mathbf{~ о ~ в ~ а : ~ A p i a c e a e , ~ O e n a n t h e , ~ H y d r o c o t y l e , ~ C y c l o s p e r m u m , ~ М ь я н м а , ~ Б и р м а , ~}$ новый виА, новинки фморы
M.F. Watson \& A. Smith (2004) had named the Umbelliferae of Myanmar (former Burma) "a last piece in the Asian puzzle" of the family. They found in British herbaria 30 additional taxa of the Umbelliferae, previously not indicated for Burmese flora. Together with additional records (Kress et al. 2003, Pimenov \& Kljuykov 2004; this contribution) the family in Myanmar includes 61 registered species in 28 genera; most of which are distributed in the mountainous northern part of Myanmar, not easily accessible up to now.

During short trip to Myanmar in February 2014 (states of Rakhine, Magway and Mandalay in Lower Burma and Chan State in Upper Burma), I met only three species of the Umbelliferae in traditional "Drude's" interpretation; all new to Burmese flora. One of these species, belonging to an affinity of Oenanthe javanica (Blume) DC., differs from the latter in some characters of leaf dissection and the shape of its terminal lobes, and is described here as a new species, O. hortorum-natantium sp.nov. Two other species from genera Hydrocotyle L. and Cyclospermum Lag., widely distributed in tropical and subtropical countries, have never been indicated for Myanmar before.

\section{A new species of Oenanthe from the state of Shan (Upper Burma)}

In $\mathrm{E}, \mathrm{SE}$ and $\mathrm{S}$ Asia, there are several closely related aquatic and paludous Oenanthe species, belonging to sect, Dasyloma (DC.) Benth. et Hook. f. They include the widely spread and polymorphic O. javanica and more locally distri- buted species, taxonomic relationships among which have been ambiguously treated by local taxonomists and botanists. Mukherjee \& Constance (1993: 80) wrote that O. javanica "is an extraordinarily variable and widespread speciescomplex", and Pu Fading \& Watson noted (2005: 131) that its "leaf morphology is particularly variable". Some names of species, described in the group are treated as almost indisputable synonyms of O.javanica (O. laciniata Blume (1826), O. stolonifera DC. (1830), O. corticata Edgew. (1846), O. subpinnata (Miq.) Drude (1898), O. japonica (Miq.) Drude (1898), O. kudoi Suzuki et Yamam. (Yamamoto 1932), and O. normanii F.P. Metcalf (1934), although the status of some of them could be changed after deep and geographically broad revision. Relationships among other species are critical according to recent and current publications (O. hookeri C.B. Clarke (1879), O. benghalensis (DC.) Miq. (1870), O. rosthornii Diels (1900), O. linearis Wall. ex DC. (1830), O. dielsii H. Boissieu (1906), O. caudata C. Norman (1929), O. hiepii Pimenov \& Kljuykov (2002), O. pterocaulon Liu Tangshui, Chao Chuangying \& Chuang Tsaniang (1961) and O. alatinervis Quin Yiyon (1989) These taxa differ from one another mainly in the shape of terminal leaf lobes. The Chinese plant author names do not abbreviated here, according to the recommendations by Xu Zhaoran \& D.H. Nicolson (1992).

Oenanthe hortorum-natantium Pimenov, sp. nov.

Holotype: MYANMAR. Shan State, Lake Inle, on “floating gardens", 2004'03.20" N, 96 57'07.23"E. $880 \mathrm{~m}$ a.s.l. 15 February 2014. M.G. Pimenov (MW) (Fig. 1). 


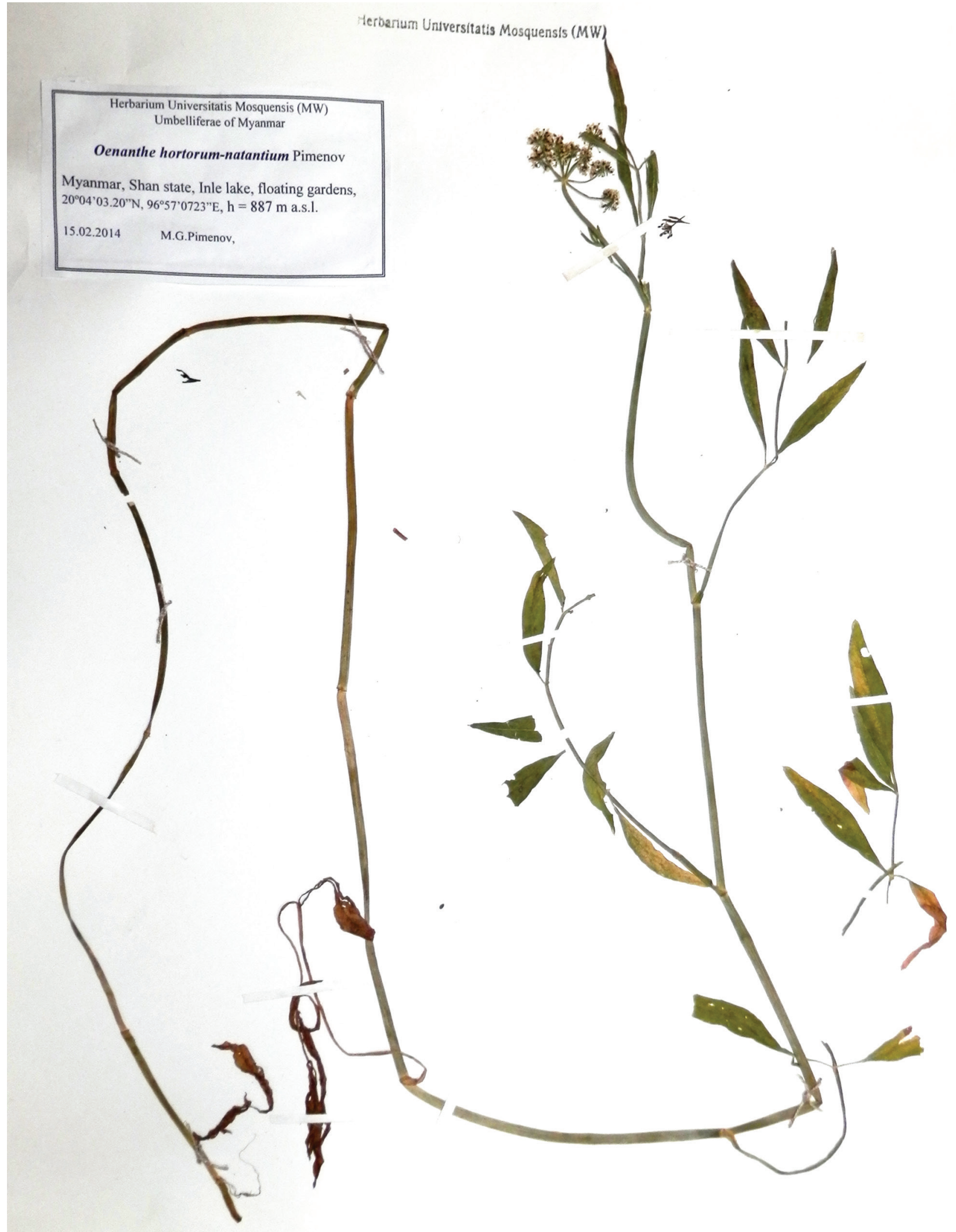

\section{HOLOTYPUS}

Figure 1 Holotype of Oenanthe hortorum-natantium Pimenov (Inle Lake) 
Desciption: Living for a few years, biennial or probably even annual glabrous monocarpic herbs, without horizontal rhizomes and stolons, growing in "floating gardens" on the lake. Stems solitary, hollow, at the base $3-4.5 \mathrm{~mm}$ in diameter, stout, flexile, $20-40 \mathrm{~cm}$ tall, in lower part submerged in moist substrate, rooting at the lower nodes, usually a little branched only in upper part. Leaves with narrow, non-inflate sheaths and long hollow petioles; leaf blades 9-14 cm long, up to $5 \mathrm{~cm}$ broad, in outline narrow triangular to triangular, loose, pinnate or rarely bipinnate, with remote, narrow lanceolate terminal segments, undivided or rarely trilaciniate with two minor lateral lacinia, with integer margins, attenuated at tips. Upper cauline leaves reduced upwards. Umbels few, somewhat solitary, axillary or terminal, 28-42 $\mathrm{mm}$ in diameter, with 4-7 rays, subequal or moderately unequal, $7-15 \mathrm{~mm}$ long, somewhat scabrous in the upper part; with peduncles $3.2-6.3 \mathrm{~cm}$ long, bracts absent. Umbellets (Fig. 2) 4.5-6 mm in diam., with 14-22 rays, somewhat scabrous in the upper part; bracteoles numerous, linear, acute, appoximately one and half shorter than umbellet rays. Flowers hermaphrodite and male. Calyx teeth prominent, narrowly triangular; petals white, glabrous, obovate, emarginate, with a narrower inflexed apex; stylopods conical, styles straight, slightly divergent. Carpophore the most probably wanting. Ovaries glabrous; fruits unknown.

Affinity: The new species belongs to sect. Dasyloma (DC.) Benth. et Hook. f., which includes a series of closely related East-Asian species. The new species differs from the section's central and most widely distributed species, O. javanica (the only known in Myanmar up to now), in short-lived monocarpic, biennial or probably annual lifeform, the absence of horizontal stolons and rhizomes, usually pinnate (against bipinnate to tripinnate) leaf blades, the shape of terminal leaf segments (narrowly lanceolate with integer margins against ovate or rhombic ovate, coarsely dentate or serrate. It was impossible to find mature or even immature fruits of the species at February for more precise diagnostics of the species in the section Dasyloma. I'd like to note, however, that the modern keys to Oenanthe species in the treatments of the genus in "Flora of China" (Pu Fading \& Watson 2005) and "Umbelliferae (Apiaceae) of India"

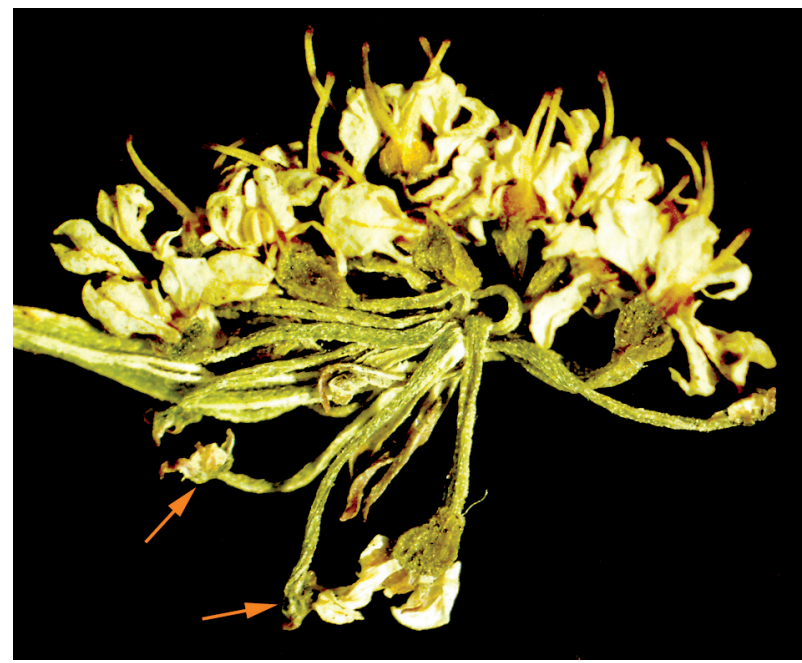

Figure 2 Umbellet of Oenanthe hortorum-natantium Pimenov from holotype (Inle Lake). Male flowers are shown by arrows

(Mukherjee \& Constance 1993) both are based presumably on the characters of dissection and terminal segment form of leaves.

Etymology: The species is named after its unusual habitat in horti natantes = "floating gardens"; hortorum - plur. gen. from hortus, $i$; natantium - plur. gen. from natans, antis.

Habitat: The habitat of the new species is very unusual; and may well be described as exotic. It grows in the so called "floating gardens" (Fig. 3) or "floating vegetable gardens" on Lake Inle, creating together with lacustrine dwellings an inimitable unique scenery. Similar floating gardens are known in Southern Asia only near Srinagar (Jammu and Kashmir State, India).

Phenology: Collected in February in the state of budding or flowering, the species presumably blooms until autumn, bearing fruits in April-November.

Note: A small series of specimens of a new Oenanthe species has been collected in locus classicus; unfortunately, the majority of them were lost to a fire in the Moscow University Botanical Garden.
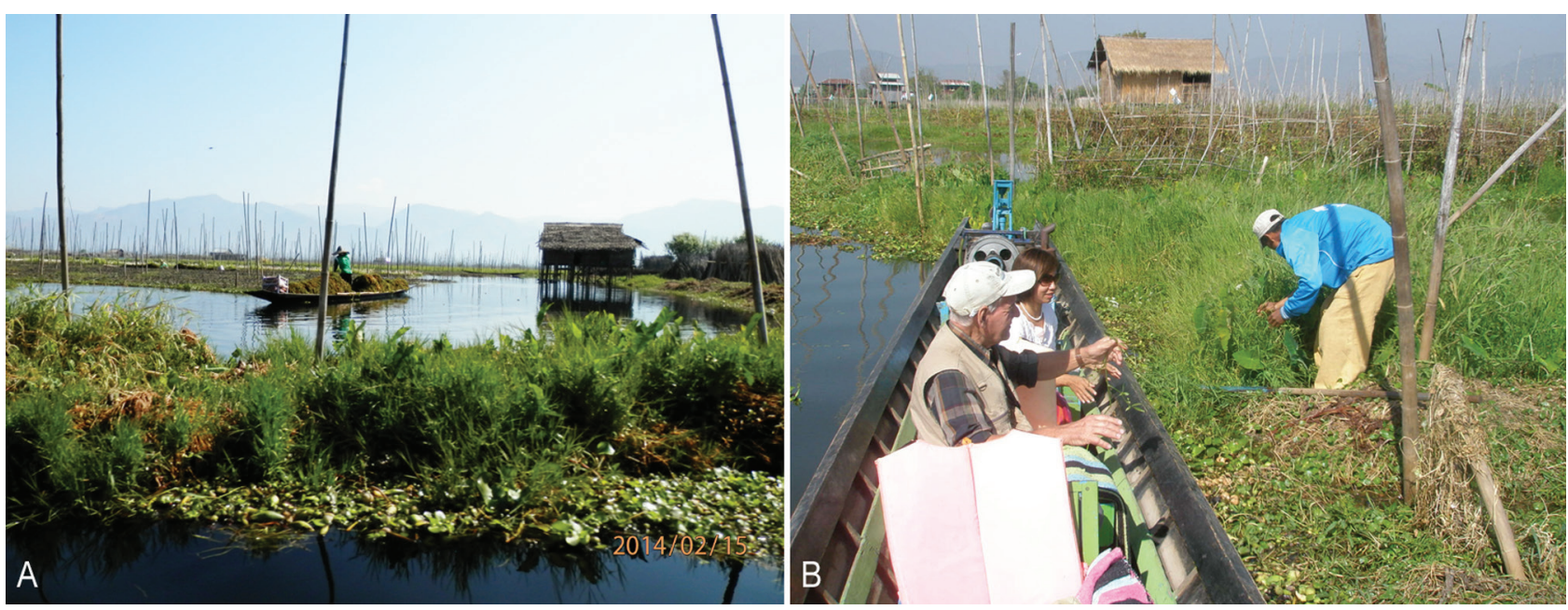

Figure 3 Floating gardens of Inle Lake - a habitat of Oenanthe hortorum-natantium in the classic locality (A) and collecting the type specimens (B) 
Two species of the Umbelliferae new for the flora of Myanmar

Hydrocotyle verticillata Thunb., Diss. Hydrocotyle 2:

t. 5.1778

Type: Country is not indicated, presumably Cape [SOUTH AFRICA] (Thunberg 6722 UPS, designated by Burtt, 1991: 219).

= Hydrocotyle vulgaris auct. non L.: Buvalda, 1936: 133; 1949: 115; 1951: 60.

Studied specimens: MYANMAR. Shan State, Pindaya, adventive plant on the meadow on the shore of small lake near Pidah-Lin Caves, 205 $55^{\prime} 42.68^{\prime \prime}$ N, 96 $40^{\prime} 17.48^{\prime \prime}$ E. 14.02.2014. M.G. Pimenov (MW) (Fig. 4); Shan State, Inle Lake, near tourist bungalows, 20 04'03.20" N, 96057'07.23"E. 15.02.2014. M.G. Pimenov (MW); Rakhine State, coast of Bay of Bengal near Ngapali. 18 ${ }^{\circ} 25^{\prime} 01.64^{\prime \prime} \mathrm{N}$, 94²17'52.46" E. 19.02.2014. M.G. Pimenov (MW).

Distribution in Asia: E Tropical (Papua - New Guinea, Indonesia, Myanmar).

Distribution outside Asia: Europe, Africa, Australia and Oceania, N, Central and S America.

Note 1: The collected specimens clearly differ from other local species of Hydrocotyle in shield-shaped (peltate) leaves with petioles attached in the central part of the lamina, which lacks grooves. Their characters clearly match those of two exceedingly similar species, $H$. vulgaris $\mathrm{L}$. and $H$. verticillata, sometimes the latter regarded as a variety of the first (see, Eichler 1987). At February the plants were without inflorescences, and for identification of the Myanmar specimens in such phonological stage, the indumentum of petioles in their upper part seems appeared to be the most significant diagnostic feature. The species differ also in the number of lamina veins, but with incomplete delimitation (8-13 in H. verticillata and 6-10 in H. vulgaris) (Cannon 1967, Gonçalves 1978). Having glabrous petioles, our gatherings are to be identified as $H$. verticillata. The species is a pantropical weed, presumably of American origin, widely

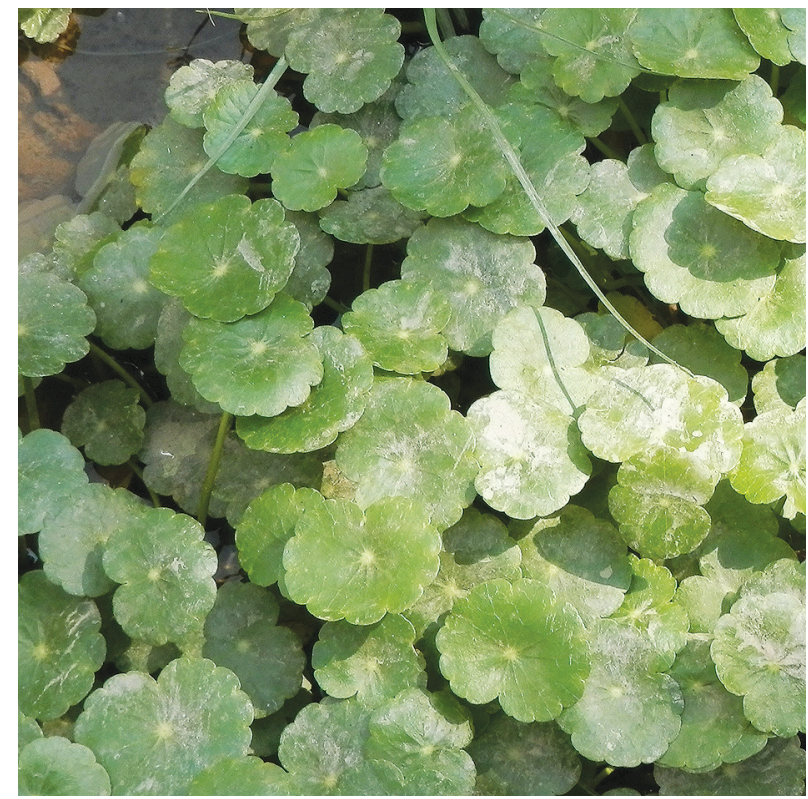

Figure 4 Hydrocotyle verticillata Thunb. (Myanmar, near Pindaya) distributed from Australia, Polynesia, New Guinea, Indonesia (recorded there under the name of $H$. vulgaris, Buwalda (1936, 1949, 1951), Israel, Madagascar, South and Tropical Africa to North, Central and South America. It is also a popular commercial water plant for aquariums. H. vulgaris is mainly an European species, reaching eastwards the Caucasus and the Iranian coast of the Caspian Sea. Recently, H. verticillata was found as an adventive plant in some other countries of South Asia, Bangladesh (Khatun et al. 2010) and Singapore ( $\mathrm{Lim}$ et al. 2014). It seems, its range is not limited only to Asia: there have been new records for Europe too (Carretero 1997).

Note 2: Here, Hydrocotyle had been traditionally regarded as a member of Umbelliferae (Apiaceae), but molecular data (Plunkett \& Lowry 2001, Plunkett et al. 2004, Chandler $\&$ Plunkett 2004) revealed its more close affinity to Araliaceae. However, there is a considerable difference, both molecular and morphological, between Hydrocotyle and Apioideae + Saniculoideae, but the morphological hiatus with Araliaceae is not lesser than with the core Umbelliferae. At present, some authors (mainly florists) classify Hydrocotyle as Umbelliferae/Apiaceae, whereas others consider it as Araliaceae. In our purely floristic note on Hydrocotyle it would be better to follow the traditional viewpoint.

Cyclospermum leptophyllum (Pers.) Sprague ex Britt. et P. Wilson, J. Bot. 61: 131. 1923

Type: AMERICA. "Ins. St. Dominica", Poiseau (syntype P).

Studied specimens: MYANMAR. Shan State, Pindaya, weed on the meadow on the shore of small lake near PidahLin Caves, 20 55'42.68" N, 96 40'17.48" E. 15.02.2014. M.G. Pimenov (MW); Shan State, between Aungban and Heho, railway enbankment.20³9'14.99" N, 9657'07.23" E. 15.02.2014. M.G. Pimenov (MW) (Fig. 5).

Distribution in Asia: Northern [Russia (Krasnodar Territory), Georgia], Eastern [China (Jiangsu, Anhui, Hubei, Fujiang, Taiwan, Guangxi Zhuang A.R., Guangdong), Japan (Honshu, Shikoku, Kyushu, Ryukyu Islands)], SouthEastern [Indonesia, Malaysia, Myanmar], Southern [India (Uttaranchal, Punjab), Sri-Lanka, Pakistan], South-Western [Iran (Gilan), Israel]. The area seems to be expansible.

Distribution outside Asia: Europa, Africa, N. America, Central America, South America, Australia and Oceania.

\section{ACKNOWLEDGEMENTS}

I thank Dr. Tatiana Ostroumova (Moscow State University) for the design of illustrations and the Russian Foundation for Basic Research (RFBR) for financial support.

\section{LITERATURE CITED}

Blume, K.L. 1826. Bijdragen ton de flora van Nederlandsch Indië. Vol. 15, pp. 851-941. Lands Drukkerij, Batavia.

Buwalda, P. 1936. The Umbelliferae of the Netherlands Indiens. Blumea 2(3):119-238.

Buwalda, P. 1949. Umbelliferae. In: Flora Malesiana, ser. I, vol. 4(2) (C.G.G.J. van Steenis, ed.), pp. 113-140, Noordhoff-Kolff N.V., Djakarta.

Buwalda, P. 1951. Notes on New Guinea Umbelliferae. Journal of the Arnold Arboretum 32: 59-66. 


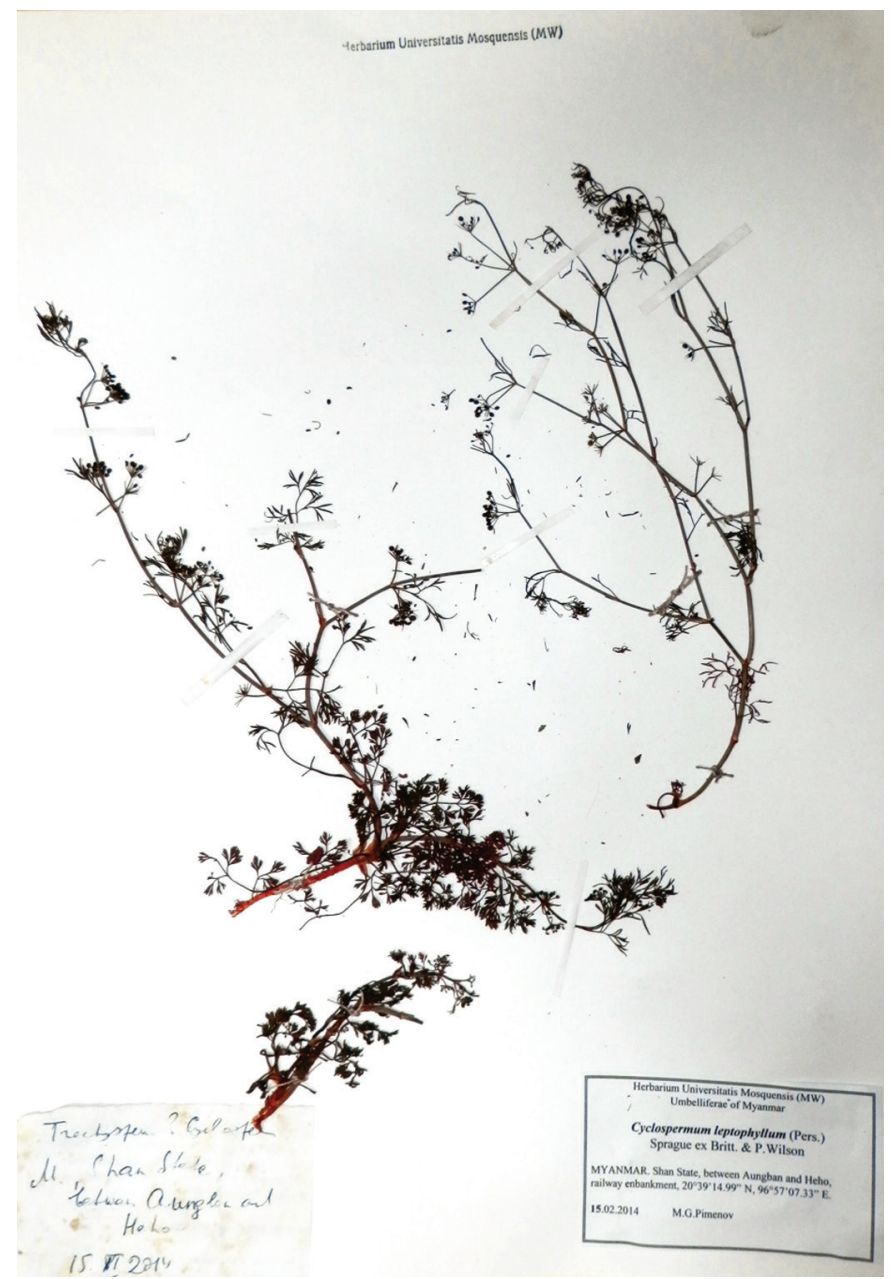

Figure 5 Cyclospermum leptophyllum (Pers.) Sprague ex Britt. et P. Wilson (Myanmar, between Aungban and Heho)

de Boissieu, H. 1906. Les Ombellifères de Cine d'après les collections de l'Academie internationale de Géographie botanique. Bulletin de l'Academie Internationale de Géographie Botanique 16:183-186.

de Candolle, A.P. 1830. Umbelliferae In: Prodromus systematis naturalis regni vegetabilium, vol. 4, pp. 55-250. Treuttel \& Würtz, Paris.

Cannon, J.F.M. 1967. Hydrocotyle vulgaris and H. verticillata. Notulae systematicae ad floram Europaeam spectantes 6 (V.H. Heywood, ed.). Feddes Repertorium 74(1-2):34-35.

Carretero, J.L. 1997. Hydrocotyle verticillata Thunb. (Umbelliferae) en la flora Ibérica. Flora Montiberica 5:63-64.

Chandler, G.T. \& G.M. Plunkett. 2004. Evolution in Apiales: nuclear and chloroplast markers together in (almost) perfect harmony. Botanical Journal of the Linnean Society 144: 123-147.

Clarke, C.B. 1879. Umbelliferae. In: Flora of British India, vol. 2 (J.D. Hooker, ed.), pp. 665-720, L.Reeve \& Co., London.

Diels, L. 1901. Die Flora von Central China. Botanische Jahrbücher für Systematik, Pflanzengeschichte und Pflanzengeographie 29(3-4):169-659.
Drude, O. 1898. Umbelliferae. In: Die Pflanzenfamilien, vol. 3(8) (A. Engler \& K. Prantl, eds.), pp. 49-192. Wilhelm Engelmann, Leipzig.

Edgeworth, M.P. 1846. On some unpublished species of plants from North-Western India. Transactions of the Linnean Society 20(1):51-58.

Eichler, H. 1987. Nomenclatural and bibliographical survey of Hydrocotyle L. (Apiaceae). Part III. Feddes Repertorium 98(5-6):273-351.

Gonçalves, M.L. 1978. Hydrocotyle. In: Flora zambesiaca 4. Rosaceae-Cornaceae (excluding Escalloniaceae \& Crassulaceae) (J.R. Timberlake \& E.S. Mertens, eds.). Royal Botanic Gardens, Kew.

Khatun, B.M.R., O. Rahman \& S.S. Sultana 2010. Hydrocotyle verticillata Thunb. (Apiaceae) - a new angiosperm record for Bangladesh. Bangladesh Journal of Plant Taxonomy 17(1): 105-108.

Kress, W.J., R.A. DeFilipps, E. Farr \& Dow Yin Yin Kyi. 2003. A checklist of the trees, shrubs, herbs, and climbers of Myanmar. Contributions from the United States National Herbarium 45: 1-590.

Lim, R.C.J., A.T.K. Yee, Xin Yi Ng \& H.T.W. Tan 2014. Whorled pennywort, Hydrocotyle verticillata Thunb. (Araliaceae), a new record of a casual aquatic macrophyte in Singapore. Nature in Singapore 7:79-91.

Liu Tangshui, Chao Chuanying \& Chuang Tsaniang 1961. Umbelliferae of Taiwan. Quarterly Journal of the Taiwan Museum 14(1-2):15-47.

Metcalf, F.R. 1934. Notes on Umbelliferae. Lingan Science Journal 13(3):517-518.

Miquel, F.A.W. 1870. Illustrations de la flore de l'A rchipel Iindien. 1. Amsterdam, Utrecht, Leipzig.

Norman, C. 1929. New Chinese Umbelliferae. Journal of Botany 67:146-148.

Pimenov, M.G. \& E.V. Kljuykov 2002. Synopsis of Umnelliferae of Vietman with description of two new species, Botanicheskii Zhurnal 87(8):126-137.

Pimenov, M.G. \& E.V. Kljuykov 2004. A new look at Kedarnatha P.K. Mukh. \& Constance (Umbelliferae). Feddes Re pertorium 115(3-4):230-238.

Plunkett, G.M., G.T. Chandler, P.P. Lowry, S.M. Pinney \& T.S. Sprenkle 2004. Recent advances in understanding Apiales and a revised classification. South African Journal of Botany 70(3): 371-381.

Plunkett, G.M. \& P.P. Lowry II 2001. Relationships among "Ancient Aralioids" and their significance for systematics of Apiales. Molecular Phylogenetics and Evolution 19(2): 259-276.

Qian Yiyong 1989. A new species of Oenanthe from Yunnan. Guibaia 8(2):117-118.

Watson, M.F. \& A. Smith 2004. The Umbellifers of Myanmar: a last piece in the Asian puzzle. South African Journal of Botany 70(3): 427-432.

Xu Zhaoran \& D.H. Nicolson. 1992. Don't abbreviate Chinese names. Taxon 43(3): 499-504.

Yamamoto, Y. 1932. Contribubiones ad floram Formosanum. IV. Transactions of Natural History Society of Formosa 22: 408-409. 